\title{
Nephelometric Method for Determination of Growth Parameters of Chlorella Culture
}

\section{A. Mitishev¹, E. Semenova ${ }^{1}$, V. Presnyakova , E. Presnyakova ${ }^{1}$, I. Moiseeva¹, S. Kolesnikova ${ }^{2}$, M. Goncharov 1 , Y. Moiseev ${ }^{1}$, and S. Presnyakov ${ }^{1}$}

${ }^{1}$ Penza State University, Ministry of Education and Science of the Russian Federation, 40 Krasnaya street, Penza, Russia

${ }^{2}$ National Research Nuclear University MEPhl (Moscow Engineering Physics Institute), Kashirskoe shosse 31, Moscow, 115409, Russia

\section{Abstract}

Nephelometric method for the determination of growth parameters of chlorella culture using a photoelectric colorimeter was described. Use of photoelectric colorimeter for cell counting in suspension requires periodic calibration of meter readings using chlorella standard culture (with a certain cell concentration). Chlorella vulgaris IPPAS C-66, IPPAS C-111 and IPPAS C-2019 strains served as object of research. Density of

Corresponding Author:

A. Mitishev

span2361@rambler.ru

Received: 22 July 2018

Accepted: 9 September 2018

Published: 8 October 2018

Publishing services provided by Knowledge E

(c) A. Mitishev et al. This article is distributed under the terms of the Creative Commons

Attribution License, which permits unrestricted use and redistribution provided that the original author and source are credited.

Selection and Peer-review under the responsibility of the Breakthrough Directions of Scientific Research at MEPhI Conference Committee.

\section{G OPEN ACCESS} initial in vitro suspensions (after inoculation) was $0.9 \mathrm{mln}$ cells/ml. Cultivation was carried out during 12 days on a Hoagland medium with a pH of 7 (temperature of $35^{\circ} \mathrm{C}$, illumination of $10 \mathrm{klx}$ ). Sample selection for analysis and measurement was carried out daily, three times per day. Based on the obtained data, readings of photoelectric colorimeter KFK-3.01 were calibrated via direct count of chlorella cells quantity in Goryaev's chamber. Use of calibration curve made it possible to reduce significantly time and error in determination of cell number in suspension cultures. The proposed technique allows counting chlorella cells in the growth and development dynamics with sufficient accuracy, high sensitivity, reproducibility and speed. It can be used for comparative determination of the growth parameters of strains in vitro, standardization of suspension cultures, semi-quantitative determination of chlorella biomass in order to predict the yield of desired product.

\section{Introduction}

At the present time, cultivation of microalgae is of great interest all over the world [1-3]. Unicellular algae (green - Chlorella, Scenedesmus, Dunaliella and blue-green Spirulina, Anacystis) are used as objects of mass cultivation [4]. Control of the growth and reproduction rates is necessary during cultivation [5]. Control can be exercised on the basis of data on their number and biomass changes. Counting chambers (Goryaev's, Franzev's, Bogorov's) and nephelometric method are used for the determination 
of growth parameters [6]. Nephelometric method of cell counting can be used for microalgae, which grows as homogeneous suspensions e.g., Chlorella, Anacystis).

Use of photoelectric colorimeter for cell counting in suspension requires periodic calibration of meter readings using chlorella standard culture (with a certain cell concentration). Data, obtained on photoelectric colorimeter, are expressed in relative units, which express total biomass of microalgae rather than cell number. However, error of such determination is significant. In most cases, it is more convenient to express the measured parameter not in the photoelectric colorimeter readings, but in the number of cells per $1 \mathrm{ml}$ of the suspension. For this, the photoelectric colorimeter is calibrated and calibration curves are made for each culture.

Aim of research - to evaluate the possibility of using a nephelometric method for determining the growth parameters of chlorella strains in suspension culture.

\section{Materials and Methods}

Chlorella vulgaris IPPAS C-66, IPPAS C-111 and IPPAS C-2019 strains served as object of research. Density of initial in vitro suspensions (after inoculation) was $0.9 \mathrm{mln}$ cells $/ \mathrm{ml}$. Cultivation was carried out during 12 days on a Hoagland medium with a $\mathrm{pH}$ of 7 (temperature of $35^{\circ} \mathrm{C}$, illumination of $10 \mathrm{klx}$ ). Sample selection for analysis and measurement was carried out daily, three times per day.

Number of cells was determined in Goryaev's chamber (double-grid) under the microscope BIOMED-3 (magnification of 10x). Nephelometry was carried out using photoelectric colorimeter KFK-3.01 (Figure 1). Experiment was conducted using the 1-mm thick cuvettes. The chlorella suspension was shaken and poured into one of the cuvettes. Transparent liquid medium for chlorella cultivation served as a control. Turbidity of suspension with precisely known number of cells was measured at a wavelength of $560 \mathrm{~nm}$ (green optical filter).

Calibration curve for the photoelectric colorimeter was prepared in the following way.

1. Chlorella vulgaris IPPAS C-66, IPPAS C-111 and IPPAS C-2019 strains were cultivated in the aforementioned conditions.

2. Fourteen standard solutions with different, precisely known number of cells were prepared from the algae suspension.

3. Measurements of diluted suspensions were carried out using the photoelectriccolorimeter KFK-3.01 in 1-mm thick cuvettes. The cuvettes were absolutely clean 


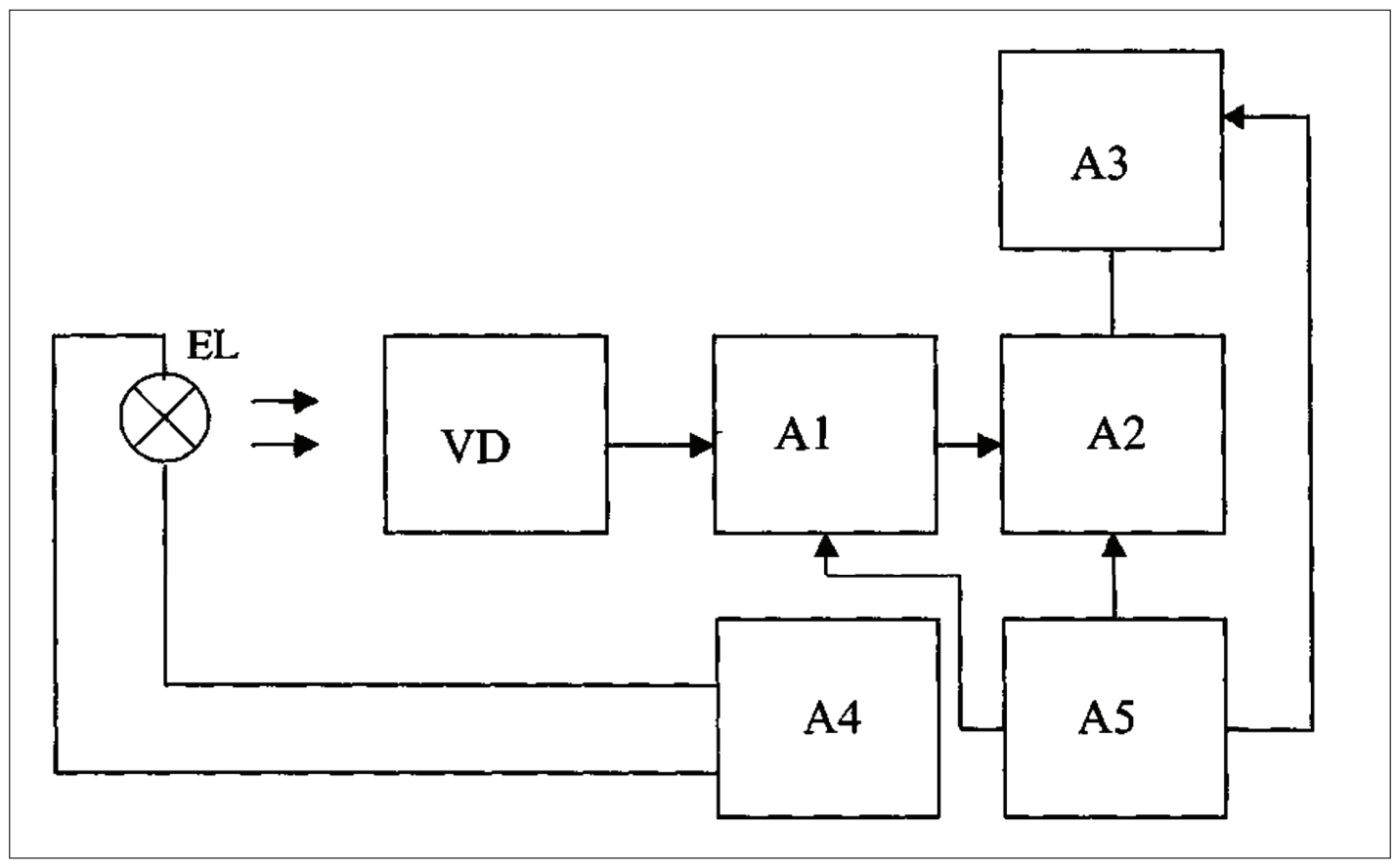

Figure 1: Circuit diagram ofphotoelectriccolorimeterKFK-3.01: EL - lighter; VD - converter of optical radiation; $A_{1}$ - DC amplifier; $A_{2}$ - microcomputer; $A_{3}$ - angle sensor of diffraction grating; $A_{4}$-stabilizer of lighter voltage; and $A_{5}$ - power supply.

and were in the same position in cuvette holder during measurement. For more accurate results, formation of air bubbles on the walls of cuvette and in suspension was carefully avoided.

4. In parallel with measuring on photoelectric colorimeter, density was counted in Goryaev's chamber (double-grid) in three replicates.

5. Calibration curve was prepared on the basis of obtained data (Figure 2).

Statistical processing of the results was carried out using the program STATISTICA 10.0 Trial Version [7].

\section{Results and Discussion}

Number of cells on $1,2,3,4,6,8,10,11,12$ days was determined according to data on optical density (Table 1 ) of chlorella suspension (C. vulgaris IPPAS C-66, IPPAS C-111 and IPPAS C-2019 strains) during cultivation (Table 2). The calibration curves (Figure 3 ) were used.

Research showed that life cycle of IPPAS № C-111 strain cells consists of the following phases. During the daytime, an active process of photosynthesis takes place. As a result, cells increase in size from 1.7 to $9.2 \mu \mathrm{m}$ (from 6 am to $9 \mathrm{pm}$ ). Biomass is also 


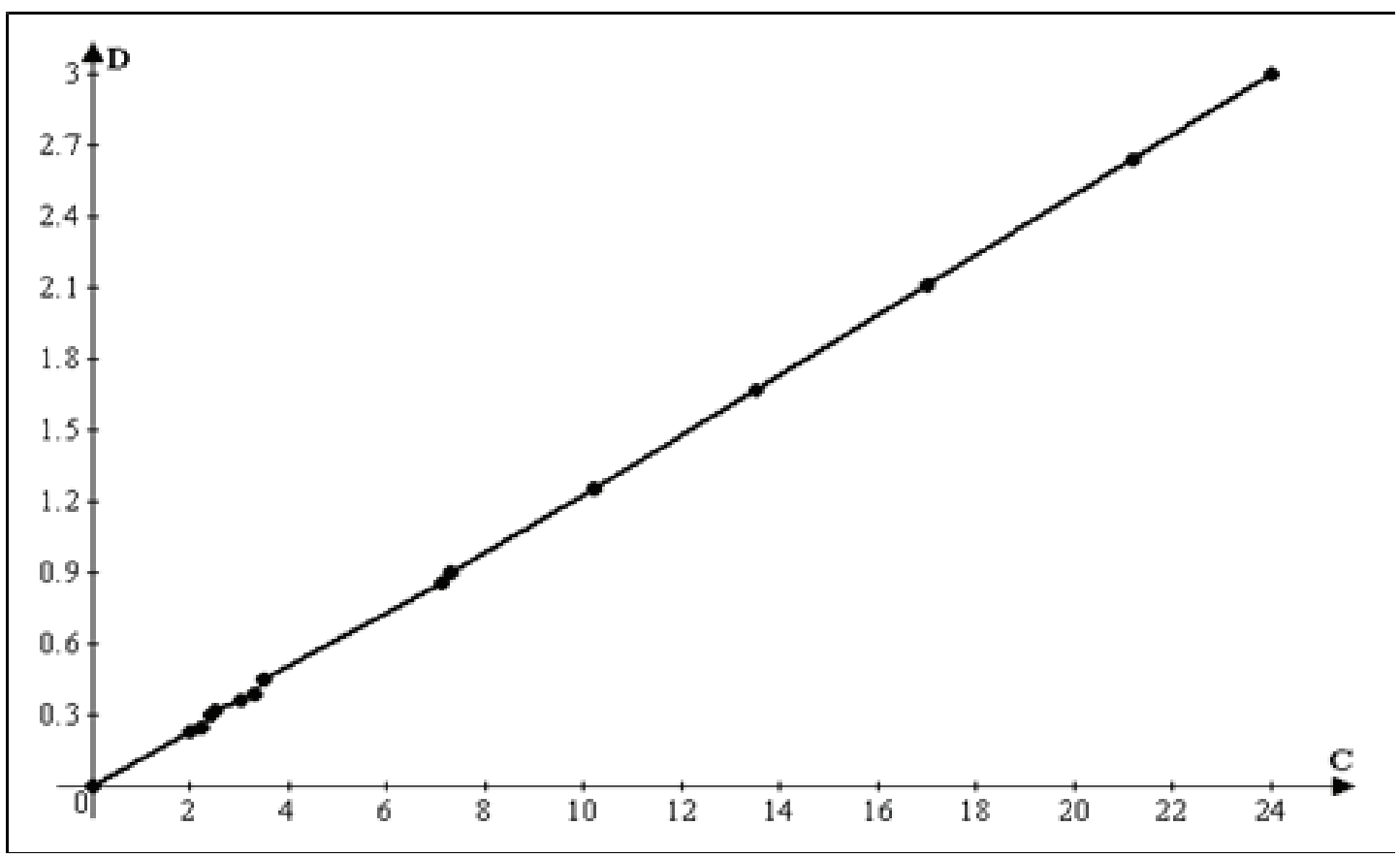

Figure 2: Calibration curve for determination of chlorella cells density in suspension culture (D - optical density; $C$ - number of cells, $10^{6}$ cells $/ \mathrm{ml}$ ).

TABLE 1: Optical density in dynamics of cultivation of IPPAS C-66, IPPASC-111 and IPPAS C-2019 strains.

\begin{tabular}{l|c|c|c|c|c|c|c|c|c|c|} 
& \multicolumn{10}{c|}{ Optical Density } \\
$\begin{array}{l}\text { Day } \\
\text { St. }\end{array}$ & 0 & 1 & 2 & 3 & 4 & 6 & 8 & 10 & 11 & 12 \\
\hline IPPAS & 0.10 & 0.17 & 0.27 & 0.36 & 0.39 & 0.80 & 1.16 & 1.24 & 1.29 & 1.28 \\
C-66 & \pm 0.00 & \pm 0.01 & \pm 0.02 & \pm 0.01 & \pm 0.02 & \pm 0.01 & \pm 0.03 & \pm 0.01 & \pm 0.01 & \pm 0.02 \\
\hline IPPAS & 0.10 & 0.19 & 0.36 & 0.51 & 0.70 & 1.48 & 2.24 & 2.49 & 2.62 & 2.50 \\
C-111 & \pm 0.00 & \pm 0.01 & \pm 0.00 & \pm 0.04 & \pm 0.04 & \pm 0.02 & \pm 0.01 & \pm 0.06 & \pm 0.01 & \pm 0.00 \\
IPPAS & 0.10 & 0.23 & 0.49 & 0.73 & 0.90 & 1.74 & 2.58 & 2.75 & 2.88 & 2.85 \\
C-2019 & \pm 0.00 & \pm 0.01 & \pm 0.06 & \pm 0.04 & \pm 0.00 & \pm 0.02 & \pm 0.01 & \pm 0.04 & \pm 0.04 & \pm 0.01
\end{tabular}

TABLE 2: Density of cells of IPPAS C-66, IPPAS C-111 and IPPAS C-2019 strain sin growth and development dynamics.

\begin{tabular}{|c|c|c|c|c|c|c|c|c|c|c|}
\hline \multirow[b]{2}{*}{$\begin{array}{l}\text { Day } \\
\text { St. }{ }^{a}\end{array}$} & \multicolumn{10}{|c|}{ Number of cells during cultivation, $10^{6} \mathrm{cells} / \mathrm{ml}$} \\
\hline & 0 & 1 & 2 & 3 & 4 & 6 & 8 & 10 & 11 & 12 \\
\hline $\begin{array}{l}\text { IPPAS } \\
\text { C-66 }\end{array}$ & $\begin{array}{c}0.90 \\
\pm 0.00\end{array}$ & $\begin{array}{c}1.40 \\
\pm 0.40\end{array}$ & $\begin{array}{c}2.30 \\
\pm 0.16\end{array}$ & $\begin{array}{c}2.90 \\
\pm 0.10\end{array}$ & $\begin{array}{c}3.30 \\
\pm 0.02\end{array}$ & $\begin{array}{c}6.60 \\
\pm 0.02\end{array}$ & $\begin{array}{c}9.50 \\
\pm 0.07\end{array}$ & $\begin{array}{r}10.10 \\
\pm 0.09\end{array}$ & $\begin{array}{r}10.50 \\
\pm 0.01\end{array}$ & $\begin{array}{l}10.40 \\
\pm 0.01\end{array}$ \\
\hline $\begin{array}{l}\text { IPPAS } \\
\text { C-111 }\end{array}$ & $\begin{array}{c}0.90 \\
\pm 0.00\end{array}$ & $\begin{array}{c}1.60 \\
\pm 0.20\end{array}$ & $\begin{array}{r}3.00 \\
\pm 0.18\end{array}$ & $\begin{array}{c}4.00 \\
\pm 0.16\end{array}$ & $\begin{array}{c}6.00 \\
\pm 0.11\end{array}$ & $\begin{array}{l}12.00 \\
\pm 0.12\end{array}$ & $\begin{array}{l}18.00 \\
\pm 0.08\end{array}$ & $\begin{array}{r}20.00 \\
\pm 0.10\end{array}$ & $\begin{array}{l}21.00 \\
\pm 0.01\end{array}$ & $\begin{array}{l}20.80 \\
\pm 0.30\end{array}$ \\
\hline $\begin{array}{l}\text { IPPAS } \\
\text { C-2019 }\end{array}$ & $\begin{array}{c}0.90 \\
\pm 0.00\end{array}$ & $\begin{array}{c}1.90 \\
\pm 0.01\end{array}$ & $\begin{array}{c}3.79 \\
\pm 0.10\end{array}$ & $\begin{array}{c}5.90 \\
\pm 0.01\end{array}$ & $\begin{array}{c}7.30 \\
\pm 0.10\end{array}$ & $\begin{array}{l}14.00 \\
\pm 0.12\end{array}$ & $\begin{array}{l}20.67 \\
\pm 0.22\end{array}$ & $\begin{array}{r}22.00 \\
\pm 0.00\end{array}$ & $\begin{array}{l}23.00 \\
\pm 0.41\end{array}$ & $\begin{array}{l}22.80 \\
\pm 0.20\end{array}$ \\
\hline${ }^{a}$ Strai & & & & & & & & & & \\
\hline
\end{tabular}

intensively accumulated in the light phase. Adult spherical chlorella cells, which are 5-8 

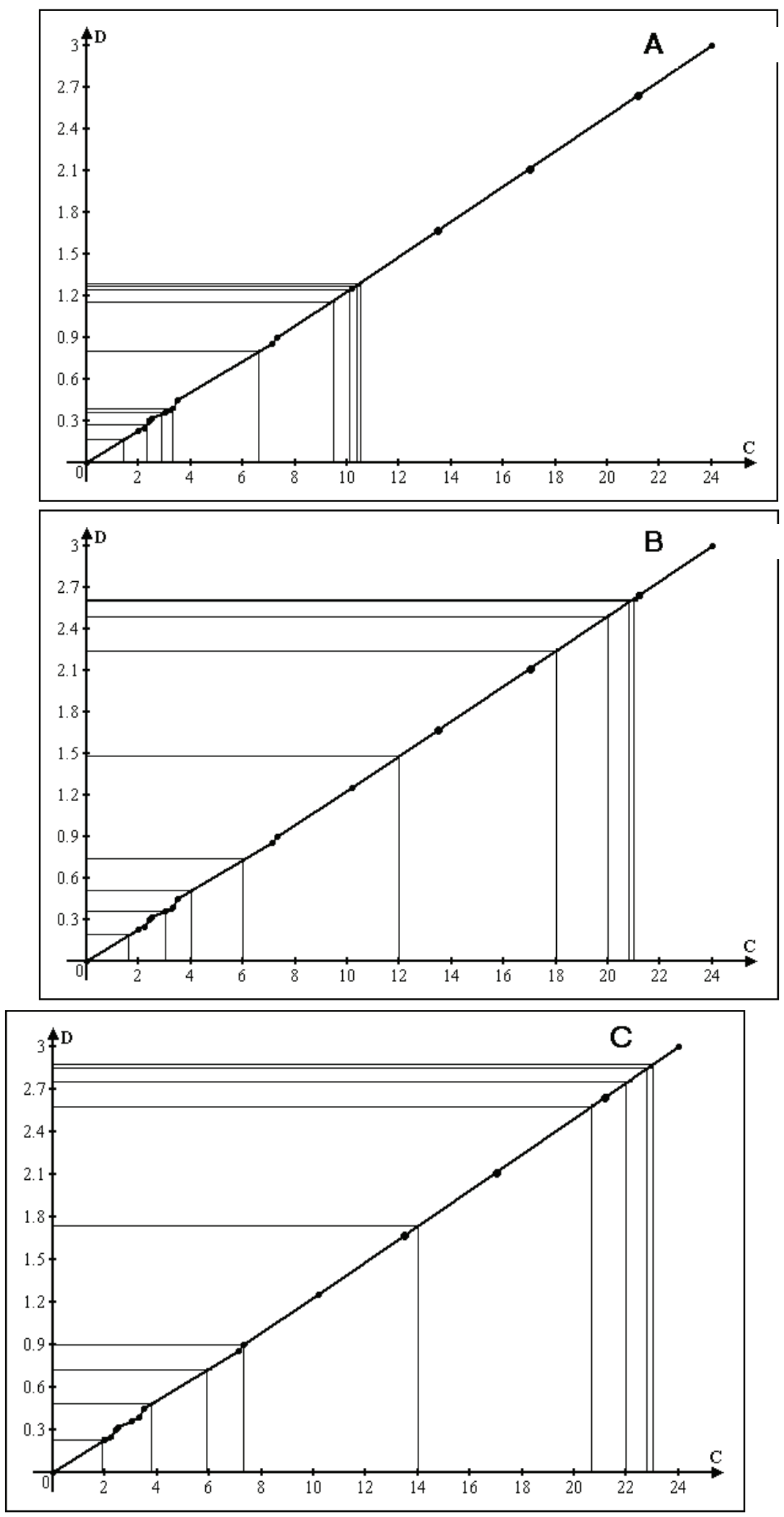

Figure 3: Density of cells of chlorella strains in cultivation dynamics: 1 - IPPAS C-66; 2 - IPPAS C-111; 3 IPPASC-2019 (D - optical density; C - number of cells, $10^{6}$ cells $/ \mathrm{ml}$ ).

$\mu \mathrm{m}$ in diameter, form the basis of biomass. Basically, cells divide into 2-8 autospores, 
very seldom into 16 . Spherical or slightly ellipsoidal in shape young cells, ranging in size from 2 to $4 \mu \mathrm{m}$, are ready for photosynthesis. Development does not depend on season of the year or light source. Stable cell growth is observed on the third day of cultivation (Figure 4). On the 10th day, culture density was $20 \mathrm{mln}$ cells/ml.

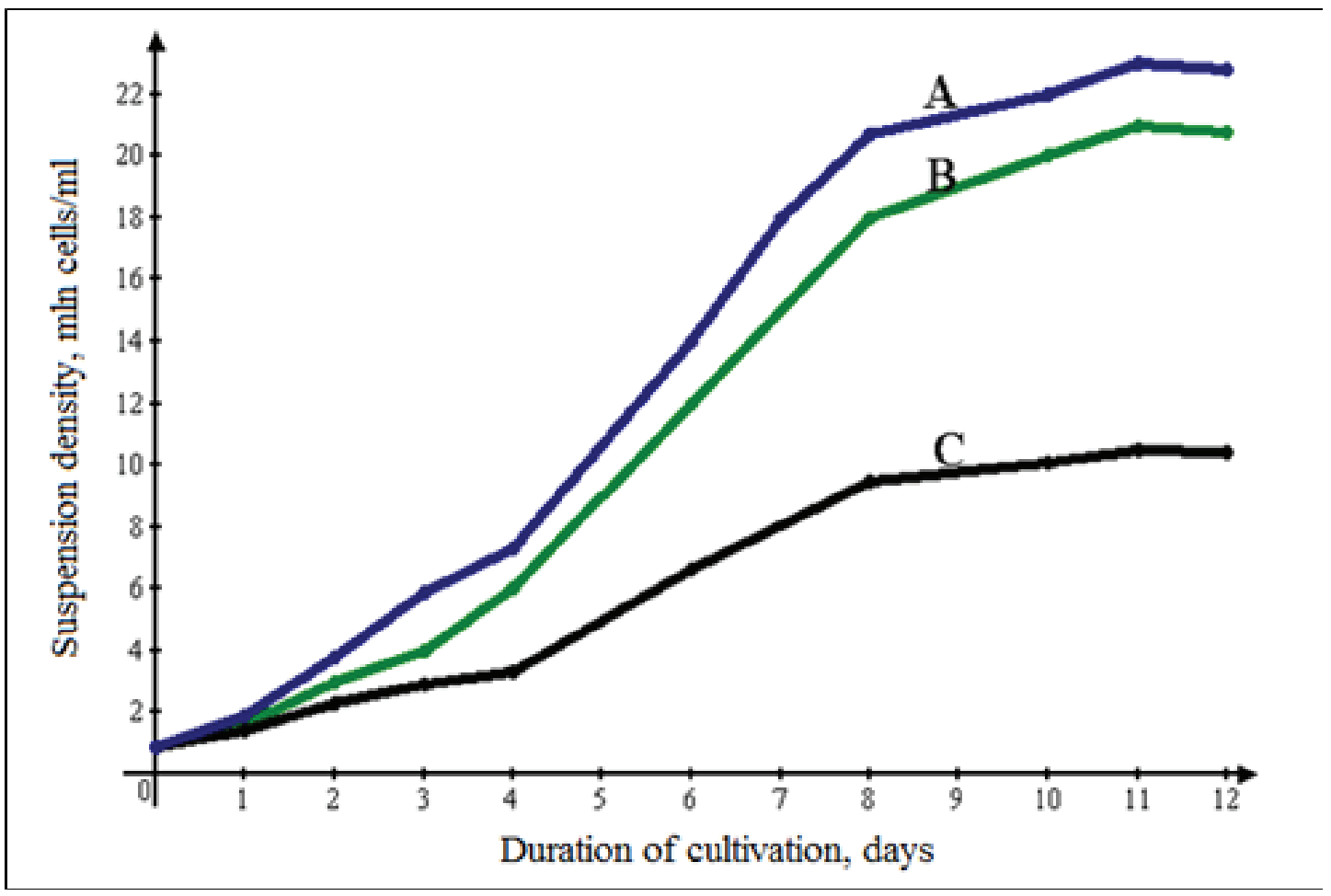

Figure 4: Growth curves of suspension cultures (A - C-2019; B - C-66; C - C-111).

The IPPASNo C-66 strain is autotrophic. Chlorella cells have different sizes during ontogenesis: at the beginning of the phase of accelerated growth they are small and dense, 1.5-2.0 $\mu \mathrm{m}$, during the stationary phase they greatly increase in size and can reach $8 \mu \mathrm{m}$. They contain a wide, belt-like, non-closed chloroplast, which is a cupshaped chromatophore. In vitro on the fourth day cell density reaches $3 \mathrm{mln} / \mathrm{ml}$ (Figure 4). On the ninth day, cell density reaches $10 \mathrm{mln} / \mathrm{ml}$.

Increase in number of cells of IPPAS S-2019 strain is observed on the second day of cultivation. Young cells have slightly ellipsoidal shape, range in size from 1.5 to 2.0 $\mu \mathrm{m}$. Adultsphericalcells, 5-8 $\mu \mathrm{m}$ in size, have pyrenoid. Chromatophore is cup-shaped, wide, belt-like, non-closed, sometimes reticulated-perforated, green or dark green in color. Flagellum is absent. In glass vessels on the fourth day, cell density reaches 7 $\mathrm{mln} / \mathrm{ml}$. On the ninth day, cell density reaches $22 \mathrm{mln} / \mathrm{ml}$. 


\section{Conclusion}

Research showed that nephelometric method is fairly accurate, simple in performing measurements of optical density. Relatively simple equipment is used. Use of calibration curve made it possible to reduce significantly time and error in determination of cell number in suspension cultures. The proposed technique allows counting chlorella cells in the growth and development dynamics with sufficient accuracy, high sensitivity, reproducibility and speed. It can be used for comparative determination of the growth parameters of strains in vitro, standardization of suspension cultures, semiquantitative determination of the chlorella biomass in order to predict the yield of desired product.

\section{References}

[1] Meshcheryakova, Yu.V., and Nagornov, S. A. (2012). Cultivation of microalgae chlorella for biofuel production. Problems of Contemporary Science and Practice (Vernadsky University), no. 12, pp. 33-36.

[2] Bogdanov, N. I. (2007). Chlorella Suspension in the Diet of Farm Animals, p. 48. Volgograd: Health and Ecology.

[3] Mitishev, A. V., Presnyakova, E. V., Semenova, E. F., et al. (2014). Comparative analysis of strains of a producer and innovative product as basic elements of biotechnology of chlorella resinoid. News of Higher Educational Institutions (Natural Sciences Series Volga region), vol. 8, no. 4, pp. 19-29.

[4] Melnikov, S. S., Manankina, E. E., Samovich, T. V., et al. (2014). Optimization of growing conditions of chlorella. Proceeding of the National Academy of Sciences of Belarus (Series of Biological Sciences), no. 3, pp. 52-56.

[5] Zazulya, A. N., Meshcheryakova, Yu. V., and Nagornov, S. A., et al. (2015). Experimental study chlorella microalgae cultivation in a tubular photobioreactor. Science in Central Russia, vol. 16, no. 4, pp. 69-76.

[6] Sirenko, L. A., Sakevich, A. I., Osipov, L. F., et al. (1975). Methods of Physiologicalbiochemical Research of Algae in Hydrobiological Practice, p. 247. Kiev: Naukova Dumka.

[7] Platonov, E. A. (2000). Statistical Analysis in Medicine and Biology, p. 52. M.: Publishing House of the Russian Academy of Medical Sciences. 